\title{
O RISO COMO AGENTE DO THAUMASTON NO TEATRO ANTIGO
}

\section{LAUGHTER AS THAUMASTON AGENT IN THE ANCIENT THEATER}

\author{
André de SENA*
}

\begin{abstract}
Resumo: O maravilhoso (thaumaston) foi discutido por Aristóteles, em Poética, e nessa obra ele está associado ao gênero épico e à tragédia, com características específicas em cada um deles; por outro lado, não se fala nessa categoria em relação à comédia. Mas neste artigo intentamos revelar alguns exemplos que contradizem isso, mostrando que a metalinguagem e o metateatro irônicos, fundamentais para uma ulterior noção do que constituiria o jogo ficcional - incluindo aí a presença do maravilhoso -, já são operados pelo riso nos palcos cômicos da Antiguidade. Através de referências a obras do teatro antigo, que ainda podem ser lidas, ou das temáticas de outras que não chegaram aos nossos dias, bem como da análise de algumas passagens dos escritos filosóficos e estéticos de Platão e Aristóteles, buscamos compreender essa possível presença do maravilhoso possibilitado pelo riso e o cômico. Neste aspecto, também nos é importante a referência a uma obra teórica específica, na verdade, o resumo de uma possível aula ou escrito anterior, hoje perdido, intitulado hodiernamente Tractatus coislinianus, que oferece - ou, ao menos, sugere - uma possibilidade teórica dessa possível plasmação do maravilhoso na comédia, já que o riso e o cômico podem proporcionar uma nova perspectiva ou prisma que incrementa a própria percepção do thaumaston.
\end{abstract}

Palavras-chave: Riso. Maravilhoso. Teatro antigo. Comédia antiga. Ironia.

Abstract: The marvelous (thaumaston) was discussed by Aristotle, in Poetics, associating it with the epic and tragedy genres, with specific characteristics in each of them, but not with comedy. This paper brings up some examples that contradict this though, showing that the ironic metalanguage and metatheater, which is fundamental for a further notion of what constitutes the fictional game - including the presence of the marvelous -, were already operated by laughter in comic stages of Antiquity. We seek to understand this possible presence of the marvelous, made possible by laughter and humor, through references to works of ancient theater that can still be read, or to themes of others that have not reached our days, as well as through the analysis of some passages from Plato's and Aristotle's philosophical and aesthetic writings. In this respect, it is important to also refer to the summary of a possible an dnow lost class or writing, which today is called Tractatus coislinianus. It offers, or at least suggests, a theoretical possibility of this amalgamation of the marvelous in comedy, since laughter and comic can offer a new perspective or prism that improves the own perception of thaumaston.

Keywords: Laughter. Marvelous. Ancient Theater. Old Comedy. Witz.

Quando o teatro clássico passou a remodalizar concretamente o que antes fora puro território da enunciação imaginativa - se 'descontarmos' a perfomance na voz e no corpo dos aedos e rapsodos que mediavam o espírito épico -, veremos que houve uma espécie de continuidade na experiência do maravilhoso (thaumaston) épico, agora performado pelas tragédias.

\footnotetext{
* Doutor em Literatura. Professor do Departamento de Letras da Universidade Federal de Pernambuco (UFPE). E-mail: andredesena.art@gmail.com. ORCID: https://orcid.org/0000-0003-2090-6398
} 
Utilizando da diferenciação modal entre mímese e diegese, trabalhada por Platão no "livro III", de A república, pode-se afirmar que nas tragédias o signo do maravilhoso geralmente se inscrevia mais na diegese - em especial nas falas dos personagens mensageiros que retransmitiam fatos portentosos em analepses, aproximando-se do que faziam os cantores épicos - do que na mímese, já que, como asseverava Aristóteles (que, por sinal, no limite não diferenciava mímese e diegese), em sua Poética, muitas coisas evocadas pela linguagem não necessariamente poderiam ser factíveis no palco (daí a dupla abertura ao thaumaston e ao alogon [irracional] na epopeia e não na tragédia, segundo o filósofo, no mesmo livro). Os personagens mensageiros e os cantores épicos estariam sob o influxo de um tipo de verossimilhança possibilitada pelos poderes divinos e a linguagem. É por isso que "o mensageiro é um narrador infiltrado dentro do drama e sua palavra é sempre digna de fé." (DUARTE, 2003, p. 10). Em outras palavras, apareceriam - o narrador épico na epopeia (amalgamado ao poeta declamador) e o personagem mensageiro na tragédia (amalgamado ao ator) - como bastiões da verdade semelhante à das Musas (nesse caso, Calíope e Clio, respectivamente), mesmo que sob a tutela, por vezes, da admiração e do maravilhoso.

Isso não quer dizer que monstros (as erínias, os ciclopes etc.), fantasmas, seres híbridos, deuses e outras tantas ocorrências 'sobrenaturais' (dentro de uma 'sobrenaturalidade' típica daquela cultura, bastante convergente com a realidade, por sinal) não fossem postos em cena, mas sua plasmação se reificava dentro dos limites estabelecidos pela visualidade e todo o aparato cênico. Estavam acima dos superpoderes de um deus, entrevistos estes, por exemplo, numa descensão ou ascensão no palco, a vigilância, o controle, o comedimento duma coisa bastante material: a grua mechané. Por outro lado, essas crias do thaumaston estão lá. Para citar um exemplo, que tenho como paradigma pioneiro do maravilhoso instrumental típico da ficção científica que só surgiria depois de milênios, lembro do personagem homônimo da perdida tragédia Talos, de Sófocles, considerado o precursor teatral dos autômatos, embora também apareça em epopeias. Era um gigante de bronze, que está magnificamente representado em cor dourada num vaso do século V a.C., atualmente em Bari, Itália, criado por Hefesto para defender Creta, com um único ponto fraco: uma espécie de "veia" sob a pele-armadura, semelhante ao calcanhar de Aquiles. Na Ilíada, a presença de uma mecânica maravilhosa é possibilitada pela tekhné divina do mesmo Hefesto:

Ao palácio de Hefesto chegou Tétis dos pés prateados: palácio imperecível, astral, eminente entre as casas imortais e brônzeo, que construíra o próprio deus de pé manco.

Encontrou-o transpirado e atarefado, de roda dos foles. 


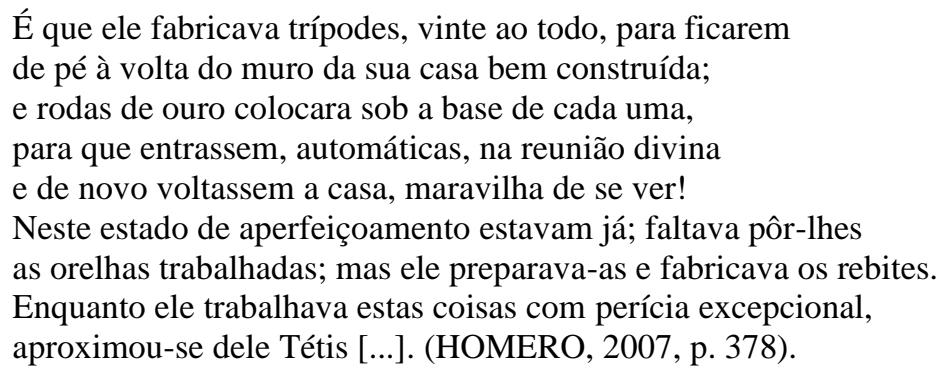

Isso também ocorria no teatro, com a personagem Talos redivivo nos palcos, outra peça da sofisticada engenharia do deus ferreiro, nessa obra dramatúrgica perdida para nosso tempo. O mito ocupava um lugar essencial na cultura helênica, e os elementos maravilhosos presentes em muitos deles não pareciam criar aporias, per se, para a representação, já que o próprio teatro se autenticara/corporificara sobre essas mesmas bases míticas. Muito provavelmente, soluções imaginativas devem ter sido propostas e executadas na mise-en-scène para contornar os problemas práticos em metáforas dramatúrgicas, literalizadas, que infelizmente nos fugiram. Assim, do pouco que restou do teatro trágico antigo, o maravilhoso, como afirmado, dá-se destacadamente no plano diegético, a exemplo do que ocorre num momento de Hipólito, de Eurípides, a partir da fala da personagem núncio, o qual relembra no palco a ocorrência de uma onda gigante que vem à terra e destrói o carro de Hipólito, e do touro que sai de dentro dela e depois mergulha, sumindo, nas pedras, aterrorizando a todos. Neste aspecto, a 'inoperosidade' do thaumaston (quase sempre atrelado ao sublime trágico) não se diferenciaria muito dos problemas técnicos usuais, mais miméticos, da lide teatral, como aquele evocado por Aristóteles, em Poética, relativo à condução de animais no palco; assim, "não há sentido comum para os centauros", como dizia um verso de Pisandro (século VI a.C.), transformado em provérbio na Antiguidade, aplicável a coisas impossíveis (PAJARES, 1999, p. 310).

Doutra monta, parece ser no absurdo risível da comédia, com toda a sua ousadia e metalinguagem, que o maravilhoso parece ter sido melhor admitido nos palcos antigos em termos de representação, de mímese mais que de diegese, com muitos elementos do que hoje chamaríamos de licença dramática. Não se pontua aqui a questão da superioridade de um gênero em relação a outro, mas algo de natureza dupla, quando não, vicária, a saber: há uma assimilação do maravilhoso na comédia, embora o riso iconoclasta e diluidor não o conjugue e autentique por completo. A desfaçatez da ironia, da paródia e do pastiche, o toca ao tempo que, chistosa e/ou metalinguisticamente, revela sua falsidade: eis a questão.

Já Ésquilo, na comédia Os emissários, ou Os participantes nos jogos ístmicos, entre outras, propunha o divertissement intertextual e o metateatro, num jogo de espelhos que chegou 
a unir duas das principais atividades socioculturais pan-helênicas do período: os jogos e o teatro. A ação se passava durante os jogos ístmicos, em Corinto, com Dioniso e os sátiros aportando, insuspeitadamente, no ambiente das competições esportivas, e estes últimos, após uma contenda com o deus da embriaguez, resolvendo servir a Posídon, o patrono da festividade. $\mathrm{O}$ auge se daria com as tentativas atléticas dos sátiros, que já revelavam, para além do riso, as ferramentas e as possibilidades que a comédia dispunha para derrubar muros e convenções.

Convenções essas que também foram contestadas num outro aspecto dentro da cultura clássica, nas tragédias híbridas de Eurípides, especialmente as de final conciliador (que também se utilizam de elementos cômicos), com a geração do processo sofístico de esvaziamento do mito, que passa a ser contemporizado, revelando-se uma nova autoconsciência histórica na própria forma e na crítica artística, também possibilitadoras de experiências metateatrais. Falo das tragicomédias, e não das tragédias euripidianas que empoderam o mito, nas quais, não à toa, fenômenos maravilhosos se presentificam diegeticamente na fala de personagens mensageiros, a exemplo de As bacantes, Medeia, Ifigênia em Áulis, a já citada Hipólito, entre outras.

Mas será na mestria cômica do teatro de Aristófanes que o riso operará um tal hibridismo, independentemente de propender ao iconoclasta ou ao reacionário dentro de cada contexto artístico e/ou empírico específico. Um voo panorâmico sobre alguns dos argumentos de suas comédias poderá revelar isso. Em A paz, um homem do povo, o lavrador Trigeu, decide voar até o céu montado num escaravelho para perguntar aos deuses o motivo pelo qual a guerra foi criada, desconstruindo o maravilhoso ligado à ascensão de personagens trágicos pela grua mechané, numa 'quebra de quarta parede' que revela os bastidores do mecanismo realisticamente, e nesse desvelar de máscaras se assume também o aspecto ficcional da encenação, que abre espaço a partir daí para qualquer situação imaginativa no palco. Por estranho que pareça, é através da lupa de um realismo extremado que se plasma por vezes o inusitado e o nonsense. Duma divertida e acintosa quebra do idealismo trágico (incluindo o associado à guerra), é pela porta aberta ao riso e à crítica social que tudo passa a poder acontecer, inclusive, o maravilhoso. Em As nuvens, o coro e os dois corifeus aparecem como personificações das nuvens, num exercício de imaginação lúdica precursor e interessante mescla de bizarria e alto lirismo, grotesco e sublime. Nela, há como uma desmaterialização dos atores, quando simulam o movimento das nuvens e sugerem - ora em sentido mimético, ora diegético - diversos efeitos e fenômenos aéreos, como a provocá-los; e, também, muitas gags jocosas logo a emparelhar-lhes. É num famoso trecho da parábase dessa peça que Aristófanes 
afirma inventar "sem cessar enredos novos, produtos de minha arte, cada um diferente do outro e todos agradáveis e alegres.” (ARISTÓFANES, 2013, p. 263), ressaltando os caracteres imaginativos de sua lavra ao tempo que achincalha a audiência com o aval dela, coisificada como "ânforas amontoadas".

Isso se repete em As vespas, também na parábase, quando diz o corifeu: "No futuro, maravilhosos atenienses, amem e honrem os poetas que buscam ideias novas e invenções." (ARISTÓFANES, 2004, p. 39). Em As aves, os seres humanos literalmente se transmutam em pássaros e desejam criar uma cidade nos ares, Nefelococigia (terra nuviosa dos cucos), uma estranha e cômica utopia aparentemente a desconstruir a tragédia perdida Tereu, na qual se diz que Sófocles mostrava a metamorfose do rei homônimo em ave. O trato imaginativo, tanto na mímese, com os atores caracterizados de aves, como na diegese, com as tiradas de gênio que endossam ainda mais o absurdo na cena (incluindo a narrativa que descreve a construção da cidade no ar), fazem dessa peça um marco histórico verdadeiro, uma utopia do inverossímil a partir do thaumaston e do alogon.

Em As rãs, há nova confluência entre mímese e diegese, em termos cênicos ligados ao maravilhoso, na viagem de Dioniso e seu escravo Xantias (quase arquétipos iniciais dos célebres personagens cervantinos) ao Hades, simulando-se, no palco, a existência e contemplação de monstruosidades e prodígios, naquele que pode ser considerado, dentre o que restou, como o maior exercício de metateatro da Antiguidade. Exercício que parece ter chegado ao auge, em termos de autorreferencialidade e liberdade composicional em Aristófanes, na peça, hoje perdida, Acampadas, que expunha as tendas de mulheres reunidas para um festival e o próprio dramaturgo como personagem no palco, imitando Eurípides. Dessarte, "esse seria o único caso, de que se tem notícia, no qual o comediógrafo fala em seu próprio nome." (SACCONNI, 2018, p. 194).

A diluição operada pelo riso é curiosamente amalgamada ao exercício do maravilhoso, incluindo-se aí também o da catarse. É como se a catarse, à qual só se chega na tragédia num determinado movimento ascendente em direção a um píncaro, se distendesse igualmente por toda a comédia, através do riso e do inusitado. Daí a necessidade de novas e, cada vez mais, elaboradas experimentações, para não cair numa possível monotonia por conta desse alargamento. A catarse geralmente é traduzida, em língua portuguesa, em termos de 'purgação' ou 'purificação' das paixões, mas acredito que seu sentido original, ao menos a partir da Poética aristotélica, esteja mais próximo de 'experienciação', ou fruição estética. A noção de 'purgação' tem origem hipocrática e está associada às antigas teorias humorais, enquanto a 'purificação' 
ressumbra um sentido ora órfico, ora moralista (o didatismo exigido para as obras artísticas, levado ao extremo em Platão, e a noção de que elas engrandeceriam as virtudes pessoais e sociais). Já a 'experienciação' - como opto em ler a catarse aristotélica relativa ao mito assume uma nova faceta no cômico, mais próxima (como uma espécie de 'primeira abertura') da noção que hoje temos da ficcionalidade como um território independente de tais usos prescritivos e moralistas. A comédia tem um papel importantíssimo nesse contexto, quando o alívio do riso parece possibilitar a desautomatização das expectativas e a quebra de regras, embora também, por vezes - como ocorre no enredo de As rãs e em determinadas parábases de Aristófanes -, possa evidenciar, sem negar o acima dito, uma certa intencionalidade moral e didática relativa ao papel dos atores e da poesia.

Sobre esse horizonte de moralismo e controle do ficcional, para Platão, a verdade difere do belo, em sentido estético. Como nos lembra uma passagem do trecho final de Filebo, em que se diz: "Agora, tornou a escapar-nos a essência do bem, para asilar-se na natureza do belo [...]" (PLATÃO, 1974, p. 178), no momento em que o personagem do diálogo se culpa por tergiversar do assunto principal que vinha comentando, ligado à natureza do uno e das ideias, e adentra brevemente o perigoso território da estética. Como sabido, isso se evidencia sobretudo em $A$ república, no sentido de que a perquirição filosófica - em Platão, conjugada à metafísica - prescindiria completamente das 'aparências das aparências', ou mímese negativa de terceiro grau que seria atinente às representações artísticas. Desse modo, fica claro como a moral subsume o ficcional:

Sócrates - Mas bastará velar sobre os poetas e obrigá-los a não introduzirem nas suas criações senão a imagem do bom caráter? Não devemos vigiar também os outros artesãos e impedi-los de introduzirem o vício, a incontinência, a baixeza e a feiúra na pintura dos seres vivos, na arquitetura ou em qualquer outra arte? E, se não puderem conformar-se a esta regra, não devemos proibi-los de trabalharem em nossa casa, com receio de que os nossos guardiães, criados no meio das imagens do vício como numa má pastagem, colham e pastem aí, um pouco cada dia, muita erva daninha e desta maneira reúnam, sem se darem conta, um grande mal na alma? Não devemos, ao contrário, procurar artistas de mérito, capazes de seguirem a natureza do belo e do gracioso, a fim de que os nossos jovens, à semelhança dos habitantes de uma terra sadia, tirem proveito de tudo que os rodeia, de qualquer lado que chegue aos seus olhos ou ouvidos uma emanação das obras belas, tal como uma brisa transporta a saúde de regiões salubres, e predispondo-os insensivelmente, desde a infância, a imitar e a amar o que é reto e razoável? [...]. E também porque o jovem a quem é dada como convém sente muito vivamente a imperfeição e a feiúra nas obras de arte ou da natureza e experimenta justamente desagrado. Louva as coisas belas, recebe-as alegremente no espírito, para fazer delas o seu alimento, e torna-se assim nobre e bom; ao contrário, censura justamente as coisas feias, odeia-as logo na infância, antes de estar na posse da razão, e, quando adquire esta, acolhe-a com ternura e reconhece-a como um parente, tanto melhor quanto mais tiver sido preparado para isso pela educação. (PLATÃO, 1999, p. 95). 
Os próprios deuses são conformados nessa mesma lógica de moralidade que visa, em última instância, pôr freios ao que o filósofo-legislador via como um exercício narrativo falso, talvez pior que a opinião (doxa):

\begin{abstract}
E ainda menos se lhes deve contar [às crianças] ou representar em tapeçarias as lutas dos gigantes e esses ódios de toda a espécie que armaram os deuses e os heróis contra os seus parentes e amigos. Ao contrário, se quisermos convencê-los de que jamais a discórdia reinou entre os cidadãos e que tal coisa é ímpia, devemos fazer com que os adultos lhes digam isso desde a infância. Cumpre ainda cuidar para que poetas componham para eles fábulas que tendam ao mesmo objetivo. Que jamais se lhes conte a história de Hera acorrentada pelo filho, de Hefesto precipitado do céu pelo pai, por ter defendido a mãe, que aquele maltratava, e os combates de deuses que Homero imaginou, quer essas ficções sejam alegóricas, quer não. Pois uma criança não pode diferenciar uma alegoria do que não é, e as opiniões que recebe nessa idade tornam-se indeléveis e inabaláveis. É devido a isso que se deve fazer todo o possível para que as primeiras fábulas que ela ouve sejam as mais belas e as mais adequadas a ensinar-lhe a virtude. (PLATÃO, 1999, p. 66).
\end{abstract}

Uma vez que os deuses estão sendo repensados, na releitura moralista do mito e das tradições anteriores, não se daria algo diferente com o maravilhoso, na perspectiva platônica, como se vê, outrossim, em passagem de Fedro. É importante o trecho inicial do diálogo, em que Sócrates e o personagem homônimo ao título comentam o absurdo dos monstros, compreendidos como simples fabulação ociosa frente ao único exercício nobre, o da filosofia alinhado ao próprio autoconhecimento:

\begin{abstract}
Sócrates - Enquanto a mim, Fedro, acho muito engenhosas todas estas explicações [referentes à interpretação dos mitos com base no universo empírico, no caso em questão, a do rapto de Orítia por Bóreas]; porém exigem agudeza de espírito e bastante esforço por parte do hermeneuta, o que não é nada de invejar, visto como depois disso ele seria obrigado a corrigir a forma dos Hipocentauros e mais a da Quimera, para, logo a seguir, ver-se abarbado com uma turba de Górgonas e de Pégasos, além de uma multidão inumerável de seres monstruosos e inconcebíveis. Perderia um tempo enorme o incrédulo que, armado apenas da vulgar sabedoria, se impusesse a tarefa de deixar aceitáveis todos esses monstros compósitos. E a razão, amigo, é a seguinte: até agora não fui capaz de conhecer-me a mim mesmo, conforme aquilo do oráculo de Delfos, donde parece-me ridículo estudar coisas estranhas, antes de saber o que, de fato, sou. Por isso, digo adeus a essas histórias e me contento com a opinião comum; como dissse há pouco, em lugar de investigar esses problemas, cuido apenas de examinar-me. Quero saber se sou algum monstro mais complexo e cheio de fumaça que Tifão, ou algum ser delicado e simples e que, por natureza, participe de um destino de algum modo divino e sem fumos de qualquer espécie. (PLATÃO, 1975, p. 36).
\end{abstract}

É interessante como a filosofia platônica como um todo faz amplo uso do mito, mas em passagens como essa se mostra a ele contrária, ainda mais utilizando-se de exemplos em que estão presentes esses seres fabulosos. Mas o auge dessas invectivas surge em meio às prolixas 
discussões sobre jurisprudência da obra Leis, em que o personagem principal do diálogo se mostra contrário ao riso:

\begin{abstract}
Não insistamos nesse ponto; o que importa é deixar bem claro a quem a lei permite ou pró́be o uso da zombaria. Não consentiremos que nenhum poeta cômico ou fazedor de iambos e de poesia lírica, por palavras ou com o emprego de imagens, com ânimo colérico ou sereno, ridicularize, de qualquer maneira, nenhum cidadão. Quem infringir tal dispositivo, a esse os presidentes dos jogos expulsarão imediatamente do território ou multarão em três minas, que serão consagradas à divindade em cuja homenagem for dedicado o concurso. Quanto aos que permitimos há pouco ridicularizarem-se reciprocamente em seus versos, confirmamos essa liberdade desde que o façam sem paixão e por brinquedo, o que de todo lhes negamos se procederem com maldade e rancor. A apreciação da matéria ficará a cargo do supervisor dos assuntos relativos à educação dos jovens; o que ele aprovar, o autor publicará, sem que possa, no entanto, ensaiar com escravos ou com cidadãos livres tudo o que for por aquele rejeitado, sob pena de ser considerado cidadão perverso e rebelde às leis. (PLATÃO, 1980, p. 376-377).
\end{abstract}

Por sua vez, e indo na direção contrária, Aristóteles, em Poética, dignifica a experiência ficcional da mímese, elevando o poeta fabulador a um patamar de universalidade superior ao do historiador, também associando-a ao conhecimento e ao prazer gerados pelo próprio ato imitativo:

Ao que parece, duas causas, e ambas naturais, geraram a poesia. O imitar é congênito ao homem (e nisso difere dos outros viventes, pois, de todos, é ele o mais imitador, e, por imitação, aprende as primeiras noções), e os homens se comprazem no imitado [...]. (ARISTÓTELES, 1966, p. 445).

Inclusive, isso também se dá relativamente ao cômico, por conta do elemento didático que estaria contido até na presença dos versos burlescos e do riso, na contramão do pensamento platônico:

\begin{abstract}
A poesia tomou diferentes formas, segundo a diversa índole particular [dos poetas]. Os de mais alto ânimo imitam as ações nobres e das mais nobres personagens; e os de mais baixas inclinações voltaram-se para as ações ignóbeis, compondo, estes, vitupérios, e aqueles, hinos e encômios. Não podemos, é certo, citar poemas deste gênero, dos [poetas que viveram] antes de Homero, se bem que, verossimilmente, muitos tenham existido; mas, a começar em Homero, temos o Margites e outros poemas semelhantes, nos quais, por mais apto, se introduziu o metro jâmbico (que ainda hoje assim se denomina porque nesse metro se injuriavam [iámbizon]). De modo que, entre os antigos, uns foram poetas em verso heróico, outros o foram em verso jâmbico. (ARISTÓTELES, 1966, p. 445-446).
\end{abstract}

Em outras palavras, a gradação moral que fez com que Platão expulsasse o poeta de sua cidade ideal, em $A$ república, e condenasse nela o riso, ausenta-se das análises aristotélicas sobre a arte, que visam antes as origens históricas, a própria forma, os metros utilizados etc., a Revista Graphos, vol. 23, n 1, 2021 | UFPB/PPGL | ISSN 1516-1536 
revelar indiretamente a importância do cômico e, também, a de seu estudo. É por isso que Aristóteles, logo após chamar Homero de "supremo poeta do gênero sério", ou seja, da epopeia sublime, é tido também como supremo inventor do imaginário e forma cômicos, graças ao Margites:

\begin{abstract}
Mas Homero, tal como foi supremo poeta no gênero sério, pois se distingue não só pela excelência como pela feição dramática das suas imitações, assim também foi o primeiro que traçou as linhas fundamentais da comédia, dramatizando, não o vitupério, mas o ridículo. Na verdade, o Margites tem a mesma analogia com a comédia que têm a Ilíada e a Odisséia com a tragédia. (ARISTÓTELES, 1966, p. 446).
\end{abstract}

Assim, tem-se uma espécie de binomia, ou seja, a presença sublime nas epopeias e tragédias equivale à presença grotesca nas epopeias e poemas épicos cômicos (Margites, Batracomiomaquia) e comédias, num arco em que se destacam mais semelhanças que diferenças, sem aportes moralistas, mas primacialmente estéticos. Se, na continuação de sua exposição, o filósofo afirma certa superioridade da tragédia, o faz nos seguintes termos:

\footnotetext{
Vindas à luz a tragédia e a comédia, os poetas, conforme a própria índole os atraía para este ou aquele gênero de poesia, uns, em vez de jambos, escreveram comédias, outros, em lugar de epopéias, compuseram tragédias, por serem estas últimas formas mais estimáveis do que as primeiras. (ARISTÓTELES, 1966, p. 446).
}

Termos esses que não excluem o riso e o cômico como o fizera anteriormente Platão; antes, revelam talvez uma escolha estética, mas sem inviabilizá-los. A comédia, como é dito logo em seguida, surge “dos solistas dos cantos fálicos, composições estas ainda hoje estimadas em muitas das nossas cidades.” (ARISTÓTELES, 1966, p. 446), sem julgamentos valorativos, visto que até mesmo nas origens trágicas o elemento cômico se fez presente, já que a tragédia encontra sua forma ideal ao se afastar

\footnotetext{
dos argumentos breves e da elocução grotesca, [isto é,] do elemento satírico. Quanto ao metro, substituiu o tetrâmetro [trocaico] pelo [trímetro] jâmbico. Com efeito, os poetas usaram primeiro o tetrâmetro porque as suas composições eram satíricas e mais afins à dança; mas, quando se desenvolveu o diálogo, o engenho natural logo encontrou o metro adequado. (ARISTÓTELES, 1966, p. 446).
}

A valorização aristotélica da comédia como forma, por fim, se consolida logo a seguir, no momento em que se depreende - teoricamente e não normativamente, é bom destacar - um certo tipo ideal de riso, talvez mais artístico, destoante da chalaça ordinária e do simples vitupério: 
A comédia é, como dissemos, imitação de homens inferiores; não, todavia, quanto a toda a espécie de vícios, mas só quanto àquela parte do torpe que é o ridículo. $\mathrm{O}$ ridículo é apenas certo defeito, torpeza anódina e inocente; que bem o demonstra, por exemplo, a máscara cômica, que, sendo feia e disforme, não tem [expressão de] dor. (ARISTÓTELES, 1966, p. 446).

Esse excerto não difere essencialmente do que antes falara Platão, em Leis, porém outra é a paleta, bem menos prescritiva. Aristóteles não renega, moralizando; prefere chamar uma determinada coisa de "menos artística", como numa passagem em que trata do reconhecimento (anagnorisis): "que seja o reconhecimento, dissemo-lo antes; mas de reconhecimento há várias espécies. A primeira e de todas a menos artística, se bem que a mais usada, por incapacidade [inventiva do poeta], é a que se efetua por sinais [...].” (ARISTÓTELES, 1966, p. 457).

É importante relembrar essas considerações reavaliativas aristotélicas em relação à poesia como um todo - e, neste nosso caso, acerca do riso e do cômico -, pois será nelas que as diversas aventuras classicistas ulteriores se basearão, para defender sua própria criação artística diante, por exemplo, do controle e prescritividade religiosos ao longo da Idade Média e, principalmente, Renascimento, incluindo-se aí a imitatio e o farto uso que tal criação fará do antigo thaumaston (agora chamado pagão) em contextos cristãos.

Contudo, como afirmado, é mister ressaltar que para Aristóteles o maravilhoso não seria muito eficiente nos palcos, se estes forem comparados à enunciação do epos, esta sim, permeável a uma abstração maior, não circunscrita ao plano do olhar exterior. E - muito importante - o conceito de thaumaston desenvolvido em Póetica, antes do mais, está amalgamado à noção de mito defendida pelo filósofo. Esta pode ser condensada como um “conjunto elaborado de elementos escolhidos e agenciados segundo uma ordem necessária, que se opõe à diversidade aleatória dos acontecimentos reais" (COSTA, 2003, p. 22), imantada imprescindivelmente à verossimilhança e à necessidade:

O maravilhoso tem lugar primacial na tragédia; mas na epopéia, porque ante nossos olhos não agem atores, chega a ser admissível o irracional, de que muito especialmente deriva o maravilhoso. Em cena, ridícula resultaria a perseguição de Heitor: os guerreiros que se detêm e o não perseguem, e [Aquiles] que lhes faz sinal para que assim se quedem. Mas, na epopéia, tudo passa despercebido. Grato, porém, é o maravilhoso; prova é que todos, quando narram alguma coisa, amplificam a narrativa para que mais interesse [...].

De preferir às coisas possíveis mas incríveis são as impossíveis mas críveis; contudo, não deveriam os argumentos poéticos ser constituídos de partes irracionais; preferível seria que nada houvesse de irracional, ou, pelo menos, que o irracional apenas tivesse lugar fora da representação, como, por exemplo, a ignorância de Édipo quanto à morte de Laio; e não dentro do próprio drama, como a descrição dos Jogos Píticos, na Electra, ou a personagem que, nos Mísios, vinda de Tegéia para a Mísia, não diz 
palavra. Ridículo é pois declarar que sem irracional não subsistiria o mito; em primeiro lugar, nem tais mitos se deveriam compor; mas, se um poeta os fizer de modo que pareçam razoáveis, esses ainda serão admissíveis, ainda que absurdos. Na verdade, tudo quanto de irracional acontece no desembarque de Ulisses inaceitável seria, em obra de mau poeta; os absurdos, porém, Homero ocultou sob primores de beleza. (ARISTÓTELES, 1966, p. 467).

Fica claro como a discussão sobre o maravilhoso e o irracional reflete elementos de ordem empírica, obviamente utilizados de maneira diversa do modus operandi do historiador, mas o poeta se utilizaria duma matéria bem semelhante. Em lugar algum de Poética, Aristóteles elucubra a respeito de criaturas monstruosas, fenômenos insólitos, choques entre diversas realidades ou possibilidades de fragmentação do real, ou mesmo a desestruturação de determinada montagem cênica no sentido de que algo efetivamente insólito pudesse fraturar ontologicamente a experiência estética. Tudo se baseia numa lógica de contiguidade e verossimilhança, tendente ao universal, como fica patente no momento em que o filósofo equipara a tragédia à comédia nos seguintes termos:

\footnotetext{
Quanto à comédia, já ficou demonstrado [este caráter universal da poesia]; porque os comediógrafos, compondo a fábula segundo a verossimilhança, atribuem depois às personagens os nomes que lhes parece, e não fazem como os poetas jâmbicos, que se referem a indivíduos particulares [...].

O que é possível é plausível; ora, enquanto as coisas não acontecem, não estamos dispostos a crer que elas sejam possíveis, mas é claro que são possíveis aquelas que aconteceram, pois não teriam acontecido se não fossem possíveis. (ARISTÓTELES, 1966, p. 451).
}

Os comediantes, segundo a primeira passagem, são inspirados pela mesma fonte de que se abeberam trágicos e épicos, a verossimilhança; e, no segundo excerto, clarifica-se o fato de que mesmo a probabilidade do que poderia ser ou vir a se tornar insólito, metaempírico, impossível, é por fim açambarcado à pura contingência do real. Se se fala em "coisas impossíveis", elas poderiam advir, até mesmo, de um erro acidental de determinado poeta, num dos momentos em que a Poética parece realmente exercer um certo controle sobre a composição, a partir de um ideal verossímil:

$\mathrm{Na}$ arte poética, erros de duas espécies se podem dar: essenciais ou acidentais. Portanto, se propostos tais objetos, a imitação resulta deficiente por incapacidade do poeta, o erro é intrínseco à própria poesia; se, pelo contrário, o defeito consiste apenas em não haver concebido corretamente o objeto da imitação - como querendo imitar um cavalo que movesse a um tempo as duas patas do lado direito - o erro não é intrínseco à poesia, como o não é qualquer que se cometa relativamente a uma arte particular (medicina ou outra), ou quando se representam coisas impossíveis [...]. Falta menor comete o poeta que ignore que a corça não tem cornos, que o poeta que a represente de modo não artístico. (ARISTÓTELES, 1966, p. 468). 
E, por fim, nas considerações sobre o paralogismo, todo esse voltar-se ao provável e ao lógico (o paralogismo como uma espécie de verossímil 'maquiado') chega ao seu ápice, quando completa: “[...] além de que às vezes o irracional parece o que o não é, pois verossimilmente acontecem coisas que inverossímeis parecem.” (ARISTÓTELES, 1966, p. 470).

Contudo, como bem lembra Costa, na Poética aristotélica, o campo de ação do poeta “cobre todo o domínio do persuasivo, ou seja, daquilo que o espectador aceita crer. Seu fazer corresponde à capacidade de organizar uma história, um mito, não the sendo exigidas, por Aristóteles, nem a invenção original, nem a fidelidade aos mitos tradicionais." (COSTA, 2003, p. 23). Isso quer dizer que se levarmos em conta que a existência do maravilhoso - nos termos postos mais acima - era ponto pacífico e garantido por uma secular tradição, não haveria problemas apriorísticos em trabalhá-los nos palcos trágicos ou cômicos. E a margem para a invenção do poeta, seja no trabalho criativo com eventos reais (que também poderiam ser manipulados ficcionalmente, segundo a teorética peripatética) ou maravilhosos e sobrehumanos, desde que respeitada uma lógica de contiguidade na história encenada, estava garantida. A ascensão do carro voador de Medeia, o surgimento dos fantasmas de Dario e Clitemnestra, as catábases ao Hades, o touro que sai das ondas... Todos esses fenômenos, que aos nossos olhos sugerem o insólito, estavam garantidos no quadro de uma milenar experiência mítica que os não distinguia, por exemplo, da astúcia de um Odisseu ou da força de um Aquiles. Um 'impossível' verossímil dentro dessa tradição épica e trágica, diverso, nesse contexto aristotélico, de se criar uma corça com características inaturais ou outra aberração proposital. Costa lembra que "o campo da mímese não se circunscreve ao da verdade, mas ao do possível" (COSTA, 2003, p. 42), ao que eu acrescentaria: um 'possível' amplamente poroso à narrativa mítica maravilhosa da tradição. Isso parece ser corroborado pelo comentário da mesma estudiosa à Poética:

No espaço da resposta à crítica quanto à infidelidade da representação do ponto de vista da verdade, o autor cita Sófocles, para mostrá-lo como exemplo de poeta que imitava as pessoas como deveriam ser (melhores do que são), e Eurípides, como poeta que as representava como eram (verdadeiras). Além dessas duas possibilidades, a representação pode corresponder à opinião comum, como as histórias que os poetas contam sobre os deuses e que, talvez, não sejam nem verdadeiras nem melhores, mas são como "dizem" (alusão à crítica de Xenófanes). Pode, ainda, haver casos em que a representação seja como "outrora", nem melhor, nem verdadeira, mas seguindo um antigo costume. Daí a mímese não se restringir a uma única visão possível do objetomodelo. (COSTA, 2003, p. 42). 
Mas a comédia antiga parece ter ido além, como dito, a ponto de desconstruir até mesmo a assente tradição e o mito convencional, confrontando a verossimilhança com o avesso de si mesma e reconfigurando o thaumaston ao lhe revelar as entranhas. No início da sexta parte de Poética, Aristóteles faz menção de que iria analisar-lhe com maior vagar: "Da imitação em hexâmetros e da comédia trataremos depois [...]" (Aristóteles, 1966, p. 447), mas tal não se dará até o final da obra. Surge disso a lenda de que uma segunda parte haveria se perdido, uma Poética II, totalmente dedicada à comédia, e a possibilidade de que um texto, oriundo ainda da Antiguidade, o chamado Tractatus coislinianus, fosse um resumo feito a partir dela, talvez pelo principal discípulo de Aristóteles, Teofrasto (372-287 a.C.).

O título moderno dessa obra é derivado do nome de Henri Charles du Cambout de Coislin (1665-1732), um religioso e membro da aristocracia que foi o proprietário do codex, a cópia manuscrita atualmente na Biblioteca Nacional de Paris, encontrado num monastério bizantino do monte Atos, na Grécia, e datado do século X. Organizada em tópicos, cada um destes pode sugerir uma possibilidade interpretativa em aberto, por isso o tradutor brasileiro Fabricio Possebon (2003) evoca o cuidado em se extrair conclusões ex silentio. O texto se inicia abordando os aspectos miméticos e não miméticos da comédia, ensejando-se seu caráter pedagógico e didático, ou seja, positivo em relação ao mito e à mise-en-scène. No quarto tópico dessa relação, confirma-se a catarse típica da comédia, "pelo prazer e riso." (HOMERO, 2003, p. 59). Seu desígnio principal, o riso, está assegurado pelos seguintes processos, em resumo, por meio da elocução e das ações: homonímia, loquacidade, paronímia, diminutivos, alteração da voz, paródia, metáfora, engano, similitude. Equipara-se a comédia à tragédia pela via peripatética, ao citar-se nela a presença do mito, caráter, intelecto, fala, melodia e espetáculo, bem como de suas partes constituintes: prólogo, parte coral, episódio e êxodo. Mas o que realmente chama a atenção é o tópico dedicado ao riso conflagrado pelas ações, que valorizam o espetáculo cênico, através destas categorias enfeixadas sob o título de "O riso das ações": do engano; da similitude; pelo uso ou para melhor ou para pior; do impossível; do possível e inconsequente; das coisas junto ao inesperado; do equipar as máscaras para o miserável; do empregar a pantomima grosseira; quando alguém, entre os que podem optar, abandona as coisas melhores e pega as piores; quando o enunciado é incoerente e sem nenhuma ordem.

Todos esses itens de pronto nos trazem à mente o teatro aristofânico, em seus aspectos mais inovadores e nonsense, mas parece estar nas categorias "do impossível” e "das coisas junto ao inesperado", essa chave teórica que buscávamos para a possibilidade da plasmação do thaumaston em sua faceta cômica. Provavelmente afirmavam a quebra de linearidade e 
contiguidade, em relação ao tempo e ao espaço, reverberando o mesmo que ocorria no plano da elocução de acordo com o ponto "quando o enunciado é incoerente e sem nenhuma ordem”, além do inaudito e sobre-humano, beirando experimentações de estranho e insólito por via do maravilhoso, num plano bastante ousado se comparado ao das tragédias.

Aristóteles, em Poética, chegou a falar num certo irracional de cunho 'artístico' que funcionaria no mito, desde que, de preferência, fora do palco, mas contíguo à fábula; porém é de se acreditar que o maravilhoso, ou até mesmo sua quebra/ressemantização pelo nonsense, inspiraram a criação dessas categorias ("do impossível" e "das coisas junto ao inesperado") do Tractatus coislinianus, como um exercício afirmador do irracional e do inverossímil que deve ter ido muito além do simples paralogismo, quiçá, no próprio palco em termos miméticos, como se observou anteriormente nas comédias propriamente ditas. Não é ocioso lembrar que os principais exercícios de binomia (união do sublime com o grotesco) e de autenticação teórica do princípio do chiste romântico, tão caros ao modo fantástico oitocentista, têm como base essas experimentações lúdicas do teatro antigo e, em especial, de Aristófanes, a ponto de, ousadamente, alguns escritores românticos chegarem a chamá-lo de "romântico", a exemplo de Alfred de Musset, na França; Álvares de Azevedo, no Brasil; e Friedrich Schlegel, na Alemanha. E o mais interessante é que, milênios antes destes, já os teóricos gregos haviam registrado essas características de quebra do verossímil em âmbito artístico: é de se supor, graças ao que hoje conhecemos como o Tractatus coislinianus.

Já chegando ao término deste trabalho, cumpre fazer uma breve rememoração dos principais pontos discutidos. Observou-se como o maravilhoso na tragédia antiga se deu pela via diegética mais que mimética, apesar de existir exemplos miméticos, perdidos (como o maravilhoso instrumental da peça Talos) ou não (a ascensão maravilhosa do carro divino em Medeia etc.). Por outro lado, discutiu-se como o riso e a ironia da comédia - muitas vezes, autoironia, a revelar precursores experimentos metateatrais, quebras genológicas e uma espécie de alargamento da catarse - foram bem mais favoráveis ao maravilhoso mimético, não apenas em Aristófanes, mas também em outros autores, a exemplo de Ésquilo, problematizando-se ainda o fato de que por vezes um realismo extremado poderia, no limite, pô-lo em suspensão. Por fim, viu-se como o riso (e a iconoclastia que geralmente a ele se associa), em suas interconexões com o thaumaston, foi tratado disforicamente por Platão, que indiretamente o acoplou à sua visão negativa da mímese, em comparação com a Poética aristotélica, a qual não apenas corroborou teoricamente a importância do riso e a forma da comédia, como também a de seu estudo, visão eufórica sobre a mímese que será consolidada pelo escrito peripatético 
Tractatus coislinianus, especialmente em termos de riso e thaumaston. Não se levou em conta o que existia artisticamente à margem do teatro oficial, atinente ao cômico, a exemplo da farsa megárica (chalaça, caricatura popularesca), a farsa fliácica (hilarotragédias, paródias de mitos) e o mimo (minidramas), estudados por Dezotti (1993). Mas um dado específico a que essa autora nos chama a atenção, revela-nos toda a importância que até mesmo os subgêneros cômicos exerceram no horizonte clássico:

\begin{abstract}
O mimo, assim como a farsa fliácica, é originário das colônias gregas do sul da Itália (Magna Grécia) e teve grande aceitação mesmo entre as classes mais cultas. Prova disso é o que se conta sobre Platão, que teria sido um grande admirador e divulgador dos mimos do Siracusano Sofrão em Atenas. Segundo Diógenes Laércio em Vida e Doutrina dos Filósofos Ilustres (III, 18), Platão teria tomado tais textos como modelo para a estruturação de seus diálogos. Aristóteles faz, na Poética, (1447b 9), uma aproximação dos mimos com os diálogos platônicos, o que confirma a suposição de uma possível influência desse gênero sobre a forma discursiva adotada por Platão para veicular seu pensamento filosófico. (DEZOTTI, 1993, p. 38).
\end{abstract}

Se o popular mimo influenciou até a forma do moralista diálogo platônico, como o riso e o cômico não haveriam de intervir em outros gêneros, categorias e experimentos, demonstrando sua medular importância, a exemplo do que ocorre em relação ao thaumaston? Foi isso que intentamos demonstrar neste texto, ao relembrar que a mistura de gêneros, a iconoclastia, o inusitado, a autorreferência, o horrorífico (lembrar do inquietante no riso sardônico ${ }^{1}$ ) etc., já se moldaram nesses palcos antigos milênios antes das experimentações dos românticos e suas modalizações fantásticas, estando em suas origens conforme eles próprios asseveraram.

\title{
Referências
}

ARISTÓFANES. A paz. Tradução de Maria de Fátima Sousa e Silva. Coimbra: INIC, 1989.

ARISTÓFANES. As vespas, as aves, as rãs. Tradução de Mário da Gama Kury. 3. ed. Rio de Janeiro: Jorze Zahar, 2004.

ARISTÓFANES. As nuvens. Tradução de Mário da Gama Kury. Rio de Janeiro: Jorge Zahar, 2013.

ARISTÓTELES. Poética. Tradução de Eudoro de Sousa. Porto Alegre: Globo, 1966.

\footnotetext{
${ }^{1}$ Conforme Minois, "Ésquilo, Sófocles, Simônidas e alguns outros mencionam essa expressão cuja origem e cujo sentido intrigavam os antigos. Para todos, o riso sardônico designa um riso inquietante, por causa de sua indeterminação. De quem e de que se ri? Não sabê-lo provoca mal-estar, como se esse riso viesse de outro lugar, do além, como uma ameaça imprecisa. Esse riso não exprime a alegria daquele que é sua 'presa', e muitos o associam à idéia de sofrimento e morte." (MINOIS, 2003, p. 28).
} 
COSTA, Lígia Militz da. A poética de Aristóteles: mímese e verossimilhança. São Paulo: Ática, 2003.

DEZOTTI, Maria Celeste Consolin. “O mimo grego: uma apresentação”. In: Itinerários:

Revista de Literatura, n. 6, p. 37-46, 1993. Disponível em: http://hdl.handle.net/11449/107372 Acesso em: 19 nov. 2020.

DUARTE, Adriane da Silva. “Apresentação”. In: ÉSQUILO; EURÍPIDES; ARISTÓFANES. O melhor do teatro grego: Prometeu acorrentado, Édipo rei, Medeia, As nuvens. Tradução de Mário da Gama Kury. Rio de Janeiro: Jorge Zahar, 2013.

EURÍPIDES. Hipólito. Tradução de Trajano Vieira. São Paulo: Editora 34, 2015.

HOMERO. Tractatus coislinianus. In: HOMERO. Batracomiomaquia: a batalha dos ratos e das rãs. Tradução de Fabrício Possebon. São Paulo: Humanitas/FFLCH/USP, 2003.

HOMERO. Ilíada. Tradução de Frederico Lourenço. Lisboa: Cotovia, 2007.

MINOIS, Georges. História do riso e do escárnio. Tradução de Maria Elena O. Ortiz Assumpção. São Paulo: UNESP, 2003.

PAJARES, Alberto Barnabé. Fragmentos de épica griega arcaica. Madri: Gredos, 1999.

PLATÃO. Diálogos: Fedro; Cartas; O primeiro Alcibíades. Tradução de Carlos Alberto Nunes. Belém: Ed. UFPA, 1975.

PLATÃO. Parmênides; Filebo. Tradução de Carlos Alberto Nunes. Belém: Ed. UFPA, 1974. PLATÃO. Leis; Epínomis. Tradução de Carlos Alberto Nunes. Belém: Ed. UFPA, 1980.

PLATÃO. A repúbica. Tradução de Carlos Alberto Nunes. 3. ed. Belém: Ed. UFPA, 2000.

SACCONI, Karen Amaral. Fragmentos de Aristófanes: estudo e tradução. Tese (Doutorado em Letras) - Universidade de São Paulo, São Paulo, 2008.

SÓFOCLES. Fragmentos. Tradução de José María Lucas de Dios. Madrid: Gredos, 1983.

Recebido em: 25/01/2021 Aceito para publicação em: 17/04/2021 